\title{
Grammatical patterns in Spanish: verbs of existence and appearance
}

\section{Carmen López Ferrero ${ }^{1}$}

\begin{abstract}
In this paper, ${ }^{2}$ I describe the grammatical patterns of a set of Spanish verbs that are frequently used in specialised discourse to provide structure, organise information in the text and function as connectors. The verbs selected for the study are the following unaccusative verbs of existence and appearance: ocurrir ('occur'), suceder ('happen/take place'), existir ('exist'), aparecer ('appear') and resultar ('turn out').

The grammatical and lexico-graphical description of these verbs is compared with the results provided by consulting the Corpus de Referencia del Español Actual (CREA) database of the Real Academia Española in three thematic fields: Science and Technology, Economics and Finance, and Law. The results of the research highlight three specific patterns of use for the unaccusative verbs of existence and appearance studied in specialised texts, placing particular emphasis on the constructions that contribute to the texture of discourse. I propose that these patterns should be incorporated into dictionaries of use ('codifiers') as lexicographical data that may enrich the information given about these words, whose meanings are clearly diffuse.
\end{abstract}

\section{Introduction: the study of vocabulary in context}

The data provided by text corpora show that many words are used most frequently in a limited number of patterns, although the number of possible

\footnotetext{
${ }^{1}$ Departament de Traducció i Ciències del Llenguatge, Facultat de Traducció i Interpretació, Universitat Pompeu Fabra, Barcelona, Roc Boronat, 138, 08018 Barcelona, Spain.

Correspondence to: Carmen López Ferrero, e-mail: carmen.lopez@upf.edu

${ }^{2}$ The research presented in this paper was carried out in the framework of the competitive national project 'Las categorías de verbo y adverbio en el DAELE' (reference HUM2006-06982), awarded by the Spanish Dirección General de Enseñanza Superior e Investigación Científica, and directed by Dr Paz Battaner Arias at the Pompeu Fabra University.
} 
uses for each word may be very large (Hanks, 2004; Hunston and Francis, 1999; and Partington, 1996). As Sinclair (1991) points out, linguistic corpora are a valuable instrument for observing language phenomena that are not usually accessible by introspection. In fact, certain words have been shown to prefer certain syntactic functions. For example, verbs can show recurrent grammatical behaviour in terms of their position in relation to the Subject or in the selection of person and tense. Lexical items are not, therefore, equally distributed throughout the functional grammatical categories, but, rather, tend to occur in certain linguistic contexts, in which one can observe the combinations that they can form part of (see the Redes dictionary; Bosque, 2004) and their preferred syntactic position.

Furthermore, distinctions in patterns are semantically relevant (Levin, 1995; and Sinclair, 1991) in that patterns can be used to distinguish different meanings of polysemous words (Hanks, 2004; and Sinclair, 1991: 53) and words that share a pattern also tend to share aspects of their meaning (Francis, 1991; and Hunston and Francis, 1999). Consequently, texts may be characterised by the way in which certain words are used. Working with corpora may reveal 'the ways to say things' in context, and the description of the way these things are said may represent the regular uses ('patterns') of vocabulary and grammar.

This paper focusses on a set of lexical items in Spanish that serve the function of organising the Thematic structure (Halliday, 1967, 1994) of a discourse and creating cohesion (Beaugrande, 1984; Halliday and Hasan, 1976; and Winter, 1978) in specialised texts. I analyse the patterns of use of a set of intransitive verbs in Spanish: existir ('exist'), ocurrir ('occur'), suceder ('happen/take place'), aparecer ('appear') and resultar ('turn out'). These verbs are referred to as unaccusative verbs of existence and appearance or presentative verbs (Bosque and Demonte, 1999). Although they are words with diffuse meaning (general words), they are highly frequent in specialised texts.

\section{Grammatical patterns}

As mentioned above, the purpose of this study is to describe the patterns of use of a particular set of Spanish verbs of existence and appearance in specific communicative contexts. Hunston and Francis (1999: 3) define 'pattern' as follows:

[...] a pattern is a phraseology frequently associated with (a sense of) a word, particularly in terms of the prepositions, groups, and clauses that follow the word. Patterns and lexis are mutually dependent, in that each pattern occurs with a restricted set of lexical units, and each lexical item occurs with a restricted set of patterns.

Grammatical patterns are characterised by four basic features: 
(1) They constitute specific syntactic structures: for example, copulative structures such as 'it is NP that', relative clauses as 'what $\mathrm{P}$ is that', and impersonal constructions such as 'it is Ved that' (Hyland, 2004; and Oakey, 2002);

(2) The lexical items that fill them tend to belong to a particular semantic type;

(3) They exhibit some degree of phraseologisation and conventionalisation; in fact, a pattern is a repeated discourse in so far as it is a way of saying things that is preferred by a community of speakers in certain contexts (Hunston, 2001, 2002; and Hyland, 2004); and,

(4) They perform a pragmatic function: they either act as discourse markers that indicate the text organisation or are related to interactive functions (Simpson, 2004). According to Nattinger and DeCarrico (1992) and Swales (2001), it is the pragmatic function of patterns as discourse markers that accounts for their high frequency of use.

Although many reference works describe grammatical patterns in academic and professional discourses in English with the tools provided by corpus linguistics (e.g., Biber, 2005; Granger, 1998; Hunston, 2002; and Trosborg and Flyvholm Jørgensen, 2005), such studies have been carried out in Spanish only very recently (e.g., Biber et al., 2006; and Cortes, 2008). This paper aims to contribute to progress in this field.

The study I present here is based on the results obtained in previous studies (López Ferrero, 2007; and López Ferrero and Torner Castells, 2008) focussing on words used in two grammatical patterns that indicate the Theme (given information) or Focus (relevant information) in specialised texts. Using corpus linguistic methodology, I compared the lexical items selected for these patterns in a set of specialised and general texts. This previous study revealed that verbs such as ocurrir ('occur'), suceder ('happen/take place'), implicar ('imply'), permitir ('allow') and suponer ('mean/imply'), for example, are used in emphatic constructions (Kovacci, 1992) or to highlight information Focus (for instance, the verb ocurrir in pseudocleft clauses of the type lo que ocurre es que-literally, 'what happens is that'). These verbs are assumed to constitute semantic categories (as established by Bosque, 2004) because they perform the same pragmatic function-signalling the Theme or the Focus of discourse - and they tend to be used in the same type of grammatical pattern.

\section{Units analysed: unaccusative verbs of existence and appearance}

The five verbs I analyse in this paper (existir, ocurrir, suceder, aparecer and resultar) are called verbs of existence and appearance (see Bosque and 
Demonte, 1999). They help to organise the flow of information in discourse in terms of Theme-Rheme structure (Halliday, 1994), ${ }^{3}$ as in Example $1^{4}$ below:

(1) En nuestro país existe una regulación específica sobre esta cuestión (CREA)

[In our country there exists a specific regulation on this question $]^{5}$

In Example 1, En nuestro pais is the Theme of the sentence, and 'una regulación específica sobre esta cuestión' is the Rheme which carries the new information in Spanish. ${ }^{6}$ Verbs of existence and appearance are also known as 'presentative verbs' because of this function of presenting new information in discourse.

These verbs can be said to be semantically 'light', like the verbs referred to as 'supporting' verbs by Piera and Varela (1999: 4415-18). The two semantic groups of verbs of 'appearance' and 'existence' are closely related, as far as modelling experiences, in the sense that the former-the verbs of appearance-refer to events or entities that 'come into existence', whereas the latter-the verbs of existence-describe the resulting state of the 'appearance' of an entity.

As for the argument structure of the verb (Levin, 1995), the entity that is presented as existing or coming into existence is semantically the verb Object argument (not the Actor). For this reason, syntactically, though it occupies the Subject position, this constituent exhibits features of a verb Object. In the Spanish clause existe una regulación especifica, the noun phrase una regulación especifica does not play the semantic role of a verb Actor, but the role of a semantic Object or Patient. Also, the Patient constituent of unaccusative verbs can be realised as a noun phrase without a determiner, as in aparecen nombres ilustres ('well-known names appear'), which is a feature of syntactic Objects.

With regard to their lexical meaning, these verbs express the fact that 'something or someone appears on the scene'. Therefore, they have a locative meaning and require an explicit or implicit Locative argument in addition to the Patient argument in the role of syntactic Subject. The Locative argument may be said to be a space-time argument, if time is understood as place

\footnotetext{
${ }^{3}$ Halliday (1994: 37) defines Theme and Rheme functions as follows: 'The Theme is the element which serves as the point of departure of the message, the part in which the Theme is developed, is called in Prague school terminology the Rheme'.

${ }^{4}$ In the examples presented here and below, boldface is used to highlight words or word combinations that are discussed in the analysis.

${ }^{5}$ All translations in the examples are my own.

${ }^{6}$ About the correspondence Given + New and Theme + Rheme, Halliday (1994: 299) explains: 'But although they are related, Given + New and Theme + Rheme are not the same thing. The Theme is what I, the speaker, choose to take as my point of departure. The Given is what you, the listener, already know about or have accessible to you. Theme + Rheme is speaker-oriented, while Given + New is listener-oriented.'
} 


\begin{tabular}{|l|l|l|}
\hline $\begin{array}{l}\text { En nuestro pais } \\
\text { (In our country }\end{array}$ & $\begin{array}{l}\text { existe } \\
\text { there exists/there is }\end{array}$ & $\begin{array}{l}\text { una regulación especifica } \\
\text { a specific regulation) }\end{array}$ \\
\hline \hline $\begin{array}{l}\text { Theme: Locative } \\
\text { prepositional phrase } \\
\text { presenting the scene, } \\
\text { from which it is } \\
\text { inferred that } \\
\text { something exists or } \\
\text { appears on the scene }\end{array}$ & $\begin{array}{l}\text { Verb of existence, } \\
\text { semantically weaker } \\
\text { than the Locative } \\
\text { prepositional phrase, } \\
\text { since it does not } \\
\text { contribute any } \\
\text { information that } \\
\text { cannot be inferred } \\
\text { from the context }\end{array}$ & $\begin{array}{l}\text { Rhement } \\
\text { which becomes the focus } \\
\text { of attention }\end{array}$ \\
\end{tabular}

Figure 1: Thematic structure for unaccusative verbs of existence and appearance in Spanish

in the time dimension (Mendikoetxea, 1999). In other words, the existence or appearance of something always implies its existence or appearance at a certain point in space or time. These verbs are therefore used frequently with adverbial expressions of place such as the deictic aqui ('here') or the $\mathrm{PPh}$ en este lugar ('at this place'). When an adverbial expression is not present, the location can usually be recovered from the context, as in, for example, existen dos posturas antagónicas [en el asunto que se está desarrollando] ('there exist two antagonistic standpoints [on the topic being developed]').

According to Delbecque and Lamiroy (1999: 1976), the unmarked clause order for these verbs is Verb-Subject, where the Subject is interpreted as the Rheme. Moreover, verbs of existence and appearance are the prototypical verbs of Locative inversion construction. ${ }^{7}$ Therefore, unless the preverbal nominal element is interpreted as the Focus, with these verbs in Spanish both the anteposition of the Locative and the postposition of the Subject noun phrase are compulsory. Hence, the clause Un monstruo apareció en el escenario ('A monster appeared on the scene') is marked, since it does not follow the canonical order of constituents - the unmarked $\times$ form being En el escenario apareció un monstruo ('On the scene appeared a monster'):

Some of the verbs I analyse here are polysemic. The verb suceder, for example, can mean 'happen' or 'take place', but also 'follow' or 'succeed somebody'. In this paper, I will only consider their meaning as part of the semantic class of unaccusative verbs.

\footnotetext{
${ }^{7}$ Unlike other verbs, in which the initial position of the Locative element is interpreted as the informative Focus in Spanish, as in Al cine se fueron los chicos, no al teatro ('To the cinema went the children, not to the theatre'), in verbs of existence and appearance, the order Locative-Verb-Subject is unmarked and is not interpreted as a contrastive Focus structure.
} 


\section{Aims of the study}

Therefore, this study attempts:

(a) To analyse the grammatical patterns of a representative group of Spanish unaccusative verbs of existence and appearance through their use in specialised texts from three fields;

(b) To determine the scope of use of these verbs in discourse: that is, whether they are used at the local level of the clause or sentence, or as connectors that help to structure and organise the discourse;

(c) On the basis of the patterns of use observed, to relate different functions of discourse: the Thematic functions (Theme and Rheme), the Syntactic functions and the Semantic verb arguments or roles; and,

(d) To consider the implications of the data provided by the discourse and corpus analysis for grammatical and lexicographic description and for teaching purposes.

\section{Corpus and methodology}

The texts I use in this study were obtained from the Corpus de Referencia del Español Actual (CREA), which is accessible at the Real Academia Española website. ${ }^{8}$ The corpus was selected according to the criteria specified under Figure 2, and the documents explored for each field are detailed under Table 1.

Due to the selection criteria, there is an imbalance in the number of texts included in each subcorpus: three books each in Science and Economics and seven books in Law, as shown under Table 1. The texts studied are thus written by few authors, but all of them are leading Spanish researchers in each field. Although this choice of corpora can affect the generalisability of the results, I consider that the representative value of texts is not questionable. The samples in the CREA corpus have been accurately selected by the Real

\begin{tabular}{|ll|}
\hline (a) Medium: & Books \\
(b) Geography: & Spain \\
(c) Fields: & Science and Technology (code 115) \\
& Economics and Finance (code 305) \\
& Law (code 317) \\
\hline
\end{tabular}

Figure 2: Corpus selection criteria

\footnotetext{
${ }^{8}$ See: www.rae.es
} 


\begin{tabular}{|c|c|c|}
\hline Field & Texts & Words \\
\hline \multirow{3}{*}{$\begin{array}{l}\text { Science } \\
\text { and } \\
\text { Tech- } \\
\text { nology }\end{array}$} & $\begin{array}{l}\text { 1 QUINTANILLA, Miguel Ángel and SANCHEZ RON, } \\
\text { José Ma (1997). Ciencia, tecnología y sociedad - Science, } \\
\text { technology and society. Santillana, Madrid }\end{array}$ & 71,566 \\
\hline & $\begin{array}{l}2 \text { SÁNCHEZ RoN, José Ma (1995). La ciencia, su } \\
\text { estructura y su futuro - Science, its structure and its } \\
\text { future. Debate, Madrid }\end{array}$ & 22,043 \\
\hline & $\begin{array}{l}3 \text { VERNET, Juan (1981). La originalidad de la Ciencia } \\
\text { Arabe (Historia de la Ciencia Arabe) - The originality of } \\
\text { Arab Science (History of Arab Science). RACEFN, } \\
\text { Madrid }\end{array}$ & $\begin{array}{l}7,617 \\
\text { ToTAL: } \\
\mathbf{1 0 1 , 2 2 6}\end{array}$ \\
\hline \multirow{3}{*}{$\begin{array}{l}\text { Econom- } \\
\text { ics and } \\
\text { Finance }\end{array}$} & $\begin{array}{l}1 \text { ALBARRACín, Jesús (1991). La economía de mercado } \\
\text { - The market economy. Trotta, Madrid, } 1994\end{array}$ & 99,721 \\
\hline & $\begin{array}{l}2 \text { Estefanía, Joaquín (1995). La nueva economía- } \\
\text { The new economy. Debate, Madrid }\end{array}$ & 23,502 \\
\hline & $\begin{array}{l}3 \text { TAMAMES, Ramón (1992). Curso de Economía - } \\
\text { Economics course. Alhambra Longman, Madrid }\end{array}$ & $\begin{array}{l}\text { TOTAL: } \\
\text { 254,584 }\end{array}$ \\
\hline \multirow{7}{*}{ Law } & $\begin{array}{l}\text { 1 ATIENZA, Manuel (1993). Tras la justicia. Una } \\
\text { introducción al derecho y al razonamiento jurídico - In } \\
\text { search of justice. An introduction to law and legal } \\
\text { reasoning. Ariel, Barcelona }\end{array}$ & 76,943 \\
\hline & $\begin{array}{l}2 \text { LÓPEZ GARRIDO, Diego (1991). El derecho de asilo - } \\
\text { The right to asylum. Trotta, Madrid }\end{array}$ & 81,944 \\
\hline & $\begin{array}{l}3 \text { PECES-BARBA, Gregorio (1983). Introducción a la } \\
\text { filosofia del derecho - Introduction to the philosophy of } \\
\text { law. Debate, Madrid }\end{array}$ & 80,733 \\
\hline & $\begin{array}{l}4 \text { SÁNCHEZ ALMEIDA, Carlos (2002). La ley de } \\
\text { Internet. Régimen jurídico de los Servicios de la } \\
\text { Sociedad de la Información y Comercio Electrónico- } \\
\text { Internet law. Legal regime of the information and e- } \\
\text { commerce society services. SERVIDOC, Barcelona }\end{array}$ & 63,300 \\
\hline & $\begin{array}{l}5 \text { Various Authors (2002). Ley 34/2002 de } 11 \text { de julio, } \\
\text { de Servicios de la Sociedad de la Información y de } \\
\text { Comercio Electrónico - Law 34/2002 dated } 11 \text { July, on } \\
\text { information and e-commerce society services. } \\
\text { SERVIDOC, Barcelona }\end{array}$ & 14,931 \\
\hline & $\begin{array}{l}6 \text { Various Authors (2002). Directiva 2000/31/CE del } \\
\text { Parlamento Europeo y del Consejo (de } 8 \text { de junio de } \\
\text { 2000) [Ley de Internet] - Guidelines 2000/31/EC of the } \\
\text { European Parliament and Council ( } 8 \text { June 2000) } \\
\text { [Internet Law]. SERVIDOC, Barcelona }\end{array}$ & 11,415 \\
\hline & $\begin{array}{l}7 \text { Various Authors (2002) Código Penal (extracto). } \\
\text { Delitos de posible comisión mediante medios } \\
\text { informáticos (La ley de Internet) - Penal Code (extract). } \\
\text { Offences that can be committed through computerized } \\
\text { media (Internet Law). SERVIDOC, Barcelona }\end{array}$ & $\begin{array}{l}\text { TOTAL: } \\
\text { 336,941 }\end{array}$ \\
\hline
\end{tabular}

Table 1: Spanish corpus of texts studied 


\begin{tabular}{|l||l|l|l|}
\hline & $\begin{array}{l}\text { Science and } \\
\text { Technology }\end{array}$ & $\begin{array}{l}\text { Economics } \\
\text { and Finance }\end{array}$ & Law \\
\hline \hline $\begin{array}{l}\text { ocurr* } \\
\text { 'occur' }\end{array}$ & $\begin{array}{l}36 \text { cases in } \\
3 \text { documents }\end{array}$ & $\begin{array}{l}124 \text { cases in } \\
3 \text { documents }\end{array}$ & $\begin{array}{l}76 \text { cases in } \\
5 \text { documents }\end{array}$ \\
\hline $\begin{array}{l}\text { suced } \\
\text { 'happen' } \\
\text { 'take place' }\end{array}$ & $\begin{array}{l}11 \text { cases in } \\
2 \text { documents }\end{array}$ & $\begin{array}{l}57 \text { cases in } \\
3 \text { documents }\end{array}$ & $\begin{array}{l}32 \text { cases in } \\
4 \text { documents }\end{array}$ \\
\hline $\begin{array}{l}\text { result* } \\
\text { 'result'/ } \\
\text { turn out' }\end{array}$ & $\begin{array}{l}25 \text { cases in } \\
2 \text { documents }\end{array}$ & $\begin{array}{l}55 \text { cases in } \\
3 \text { documents }\end{array}$ & $\begin{array}{l}135 \text { cases in } \\
7 \text { documents }\end{array}$ \\
\hline $\begin{array}{l}\text { aparec } * \\
\text { 'appear' }\end{array}$ & $\begin{array}{l}23 \text { cases in } \\
3 \text { documents }\end{array}$ & $\begin{array}{l}80 \text { cases in } \\
3 \text { documents }\end{array}$ & $\begin{array}{l}84 \text { cases in } \\
4 \text { documents }\end{array}$ \\
\hline $\begin{array}{l}\text { exist* } \\
\text { 'exist' }\end{array}$ & $\begin{array}{l}130 \text { cases in } \\
3 \text { documents }\end{array}$ & $\begin{array}{l}132 \text { cases in } \\
3 \text { documents }\end{array}$ & $\begin{array}{l}126 \text { cases in } \\
6 \text { documents }\end{array}$ \\
\hline
\end{tabular}

Table 2: Gross results of the CREA search: frequency of occurrence

Academia Española as standard examples of contemporary use of Spanish language.

In order to compare findings, the results are presented as percentages, since the total number of words for each field is different, (approximately 100,000 for Science and Technology, 250,000 for Economics and Finance, and 330,000 for Law).

The most frequent grammatical patterns for the unaccusative verbs studied were established for each field. The results of an initial corpus search are presented under Table 2; the number of cases analysed are indicated for each lexical item.

The most frequent uses for each field were established by analysing up to the first 200 occurrences of each word when the number of occurrences was greater. ${ }^{9}$

\section{Qualitative results and discussion}

Three patterns identified in the corpus analysis illustrate the recurrent use of Spanish unaccusative verbs of existence and appearance in this work: a pattern in which these verbs introduce new information (Rheme) in the sentence (see Section 6.1), a metadiscursive pattern in which the previous Theme in the discourse is recovered to focus on information considered relevant for the reader (see Section 6.2), and a phraseological pattern that applies only to some of the verbs and in particular fields (see Section 6.3). In

${ }^{9}$ Occurrences are referred to as casos ('cases') in the RAE database. 
the following sections, these patterns of use and the peculiarities I observed for each specialised field are presented.

\subsection{New information pattern}

The first pattern identified for the Spanish unaccusative verbs I analysed was one in which these verbs are used to present new information, with the Subject as Rheme in postverbal position - the unmarked order described in Spanish grammars. This pattern is particularly frequent with the verb existir, usually in the plural and in main clauses, as in Example 2:

(2) Ligado a estos temas, pero en un dominio científico diferente - el de las ciencias de la computación, fundamentalmente (también afecta a la psicología)-, se encuentra la cuestión de la inteligencia artificial; [...] En este punto existen dos posturas antagónicas [...] (Sánchez Ron, José M. 1995. La ciencia, su estructura y su futuro. Debate, Madrid, p. 56)

[Linked to these matters, but in a different scientific domain (mainly that of computational sciences though it also affects psychology), is the issue of artificial intelligence; (...) On this point, there exist two antagonistic standpoints (...)]

Example 3 illustrates the use of the verb aparecer in this pattern:

(3) Cuando pasamos a la física, ciencia que había experimentado un desarrollo importante durante el primer tercio del siglo, nos encontramos con que el exilio en sí se debe valorar de manera más cuidadosa. Es cierto que entre los físicos exiliados aparecen nombres ilustres, como el de Blas Cabrera. (Quintanilla, Miguel Ángel; Sánchez Ron, José M. 1997. Ciencia, tecnología y sociedad. Santillana, Madrid)

[When we turn to physics, a science which had undergone major development during the first third of the century, we find that exile in itself should be valued more carefully. It is true that among exiled physicists there appear well-known names, such as that of Blas Cabrera.]

In this pattern, besides presenting new information, the verbs help to organise the structure of the discourse. This is particularly clear in Examples 4 and 5:

(4) En la sentencia que ahora nos interesa, como antecedentes de hecho aparecen los tres siguientes:

primero. Probado, y así se declara, que el procesado M.R.C., nacido el 15 de noviembre de 1963 [...] (Atienza, Manuel 1993. 


\begin{tabular}{|l|l|l|}
\hline $\begin{array}{l}\text { Locative-temporal } \\
\text { complement }\end{array}$ & Verb & $\begin{array}{l}\text { Subject [Rheme or } \\
\text { Focus] }\end{array}$ \\
\hline $\begin{array}{l}\text { Ex. 2 above: On this point } \\
\begin{array}{l}\text { Ex. 3 above: among the } \\
\text { exiled physicists }\end{array}\end{array}$ & $\begin{array}{l}\text { (there) } \text { exist } \\
\text { (there) appear } \\
\text { Ex. 5 above: } \text { in the } \\
\text { meantime }\end{array}$ & $\begin{array}{l}\text { two antagonistic } \\
\text { standpoints } \\
\text { well-known names } \\
\text { many things }\end{array}$ \\
\hline
\end{tabular}

Table 3: Pattern for unaccusative verbs used to present new information (R)

Tras la justicia. Una introducción al derecho y al razonamiento jurídico. Ariel, Barcelona, pp. 7-8) [In the sentence we are now dealing with, as previous findings of fact there appear the following three:

first. Proven, and thus he declares himself, that the accused M.R.C., born on 15th November 1963 (...)]

(5) Después de la Segunda Guerra Mundial, la economía de mercado se volvió a regir por un sistema de tipos de cambio fijos pero, entre tanto, ocurrieron muchas cosas [...] (Albarracín, Jesús 1991. La economía de mercado. Trotta, Madrid, p. 258)

[After the Second World War, the market economy was once again governed by a system of fixed exchange rates but, in the meantime, many things occurred.]

The structure of this pattern, which can be referred to as Rhematising (R), is schematically presented under Table 3 .

\subsection{Metadiscursive pattern}

The Rhematising pattern discussed under Section 6.1 exhibits the canonical order of elements in the sentence. In contrast, in the metadiscursive pattern a different syntactic and discursive behaviour is observed, as illustrated in Example 6-a complex one, because it presents various patterns of the verbs analysed:

(6) [...] en ningún momento se han producido problemas de desabastecimiento que hayan paralizado el funcionamiento de la economía. No ha ocurrido en 1973 ni en 1979 y ni siquiera ha sucedido en 1991, cuando la mayor zona de producción del mundo estaba en guerra, lo que debería haber dificultado la extracción y la distribución, y centenares de pozos ardían en Kuwait. No existen perspectivas de desabastecimiento, al menos en el plazo de duración de una vida humana, y es lamentable que así suceda[...] 
Las repercusiones económicas fundamentales se producen a través de las variaciones en su precio. Es esto lo que ha ocurrido en las tres crisis energéticas y no que el abastecimiento haya estado en peligro. (Albarracín, Jesús 1991. La economía de Mercado. Trotta, Madrid, p. 210)

$[(\ldots)$ at no time have problems of supply stoppages occurred which have paralysed the running of the economy. It did not occur in 1973 or in 1979 and nor did it happen even in 1991, when the largest world production area was at war, which ought to have hindered extraction and distribution, and hundreds of wells were ablaze in Kuwait. There exist no prospects of supply stoppage, at least not in a human lifetime, and it is regrettable that this should be the case (...)

Fundamental economic repercussions arise through variations in its price. This is what has happened in the three energy crises and not that supplies have been in danger.]

In Example 6, the information that is regarded as important for the argumentative development of the text is highlighted by word order inversion in the first instance of the verb ocurrir, and by a cleft structure in the second one. In both cases, the highlighted information is found in the Locative argument: a temporal Locative in the first case ("No ha ocurrido en 1973 ni en 1979 y ni siquiera ha sucedido en 1991') and a spatial Locative in the second ('Es esto lo que ha ocurrido en las tres crisis energéticas y no que el abastecimiento haya estado en peligro'). Furthermore, in the latter, the constrastive Focus structure highlights both the subject (esto) and the Locative argument.

Example 6 is also complex because it includes different uses of the verbs ocurrir, suceder and existir that illustrate the two patterns discussed so far. In these cases, the verbs ocurrir and suceder have the Locative element in postverbal position and pick up a previous Theme by means of an elliptical (ocurrir in the first paragraph) or expressed anaphora (the adverb asi in the second occurrence of suceder in the first paragraph, and the pronoun esto in ocurrir in the second one).

In Examples 7 and 8, the Locative is highlighted by other grammatical units -in 7, the adverbs precisamente, and in 8, también:

(7) La protección de los derechos humanos es vista en demasiadas ocasiones como un problema más que como una solución. Esto es lo que sucede precisamente con el tema del asilo. (López Garrido, Diego 1991. El derecho de asilo. Trotta, Madrid, p. 11)

[The protection of human rights is all too often seen rather as a problem than a solution. This is what happens precisely with the question of asylum.] 
(8) Lo mismo que ocurre en el campo del conocimiento científico, también en el de las técnicas existen fraudes, pseudotecnologías y sucedáneos de técnicas.

(Quintanilla, Miguel Ángel; Sánchez Ron, José M. 1997. Ciencia, tecnología y sociedad. Santillana, Madrid)

[As happens (literally, 'the same as what happens') in the field of scientific knowledge, also in technology there exist frauds, pseudotechnologies and substitute techniques.]

The construction introduced by Lo mismo que ocurre en... in Example 8 is frequent in the corpus studied and can be regarded as a highly productive prefabricated structure for specialised discourses. Therefore, syntactic patterns that help to follow the argumentative structure of the text can be described as characteristic of the texts studied. In these examples, the verbs introduce a pause in the discourse and pick up previously presented information in order to focus attention on a particular element. The highlighted information is presented as a prepositional phrase that expresses a Locative complement. The Focus is not, therefore, on the syntactic Subject (as in the Rhematising pattern) but rather on the Locative argument. The use of unaccusative verbs of existence and appearance in this pattern can thus be said to perform both a cohesive and a signalling function (Fernández Ramírez, 1985-1987), in the sense that they direct the reader's attention to information that is presented as important at this point in the discourse.

Of the five verbs analysed, this use is particularly characteristic for ocurrir and suceder, which were found to occur frequently preceded by anaphoric or cataphoric proforms in the pattern presented under Table 4.

\begin{tabular}{|c|c|c|c|c|c|}
\hline $\begin{array}{l}\text { (i) } \\
\text { Discursive } \\
\text { function }\end{array}$ & $\begin{array}{l}\text { anaphora/cataphora } \\
\text { of the Theme }\end{array}$ & hinge & $\begin{array}{l}\text { syntactic } \\
\text { nexus }\end{array}$ & $\begin{array}{l}\text { presenter of } \\
\text { Focus }\end{array}$ & $\begin{array}{l}\text { information } \\
\text { Focus }\end{array}$ \\
\hline \multirow{2}{*}{$\begin{array}{l}\text { (ii) } \\
\text { Grammatical } \\
\text { categories }\end{array}$} & $\begin{array}{l}\text { (a) demonstrative } \\
\text { pronoun }\end{array}$ & \multirow{2}{*}{$\begin{array}{l}\text { copulative } \\
\text { verb }\end{array}$} & \multirow{2}{*}{$\begin{array}{l}\text { relative } \\
\text { pronoun }\end{array}$} & \multirow{2}{*}{$\begin{array}{l}\text { verb of } \\
\text { existence } \\
\text { and } \\
\text { appearance }\end{array}$} & \multirow{2}{*}{$\begin{array}{l}\text { locative } \\
\text { argument }\end{array}$} \\
\hline & $\begin{array}{l}\text { (b) comparative } \\
\text { structure or anaphoric } \\
\text { adverb }\end{array}$ & & & & \\
\hline \multirow[b]{2}{*}{$\begin{array}{l}\text { (iii) } \\
\text { Frequent } \\
\text { lexical units }\end{array}$} & $\begin{array}{l}\text { (a) esto 'this', eso } \\
\text { 'that', ello 'it' }\end{array}$ & $e s$ 'is' & $\begin{array}{l}\text { lo que - } \\
\text { 'what' / } \\
\text { 'which' }\end{array}$ & \multirow[b]{2}{*}{$\begin{array}{l}\text { ocurrir } \\
\text { suceder }\end{array}$} & \multirow[b]{2}{*}{$\begin{array}{l}\text { prepositional } \\
\text { phrase of } \\
\text { place or time } \\
\text { introduced } \\
\text { by the preps. } \\
\text { en 'in' and } \\
\text { con 'with' }\end{array}$} \\
\hline & $\begin{array}{l}\text { (b) al igual que 'just } \\
\text { as', como 'as', de la } \\
\text { misma forma 'in the } \\
\text { same way', lo mismo } \\
\text { (que) 'as' (literally, } \\
\text { 'the same as what'), } \\
\text { asi 'thus' }\end{array}$ & & & & \\
\hline
\end{tabular}

Table 4: Pattern with cohesive and focalising function 
Table 4 shows that the anaphoric recovery of the Theme in this pattern is frequently done with comparative structures of the type illustrated in Examples 9 and 10:

(9) Dentro de la realización de apuestas a distancia se menciona, entre otros sistemas, la utilización de la Red MINITEL, análoga a la que existía en España con el nombre de IBERTEX. (Sánchez Almeida, Carlos 2002. La ley de Internet. Régimen jurídico de los Servicios de la Sociedad de la Información y Comercio. SERVIDOC, Barcelona)

[Within the field of distance betting, among other systems mentioned is the use of the MINITEL network, similar to the one that existed in Spain under the name IBERTEX.]

(10) Generalmente, las empresas dedican más esfuerzos a actividades de desarrollo experimental que de investigación básica o aplicada, aunque en algunos sectores industriales el elevado nivel científico de las innovaciones tecnológicas hace difícil establecer los límites entre el interés puramente científico y el interés industrial por la investigación. Tal sucede, por ejemplo, en la industria farmacéutica, en la aeronáutica y en buena parte de la industria electrónica actual.

(Quintanilla, Miguel Ángel; Sánchez Ron, José M. 1997. Ciencia, tecnología y sociedad. Santillana, Madrid)

[Generally, companies devote more effort to experimental development activities than to basic or applied research, although in some industrial sectors the high scientific level of technological innovations makes it difficult to establish the limits between the purely scientific interest and the industrial interest in research. This occurs, for example, in the pharmaceutical industry, in aeronautics and in much of today's electronics industry.]

These patterns tend to occur at the beginning of sentences and after a pause: a comma (Example 9), a full stop (Example 10), or even a strong pause indicated by a full stop and a new paragraph (Example 8). In fact, this pattern was frequently found at the beginning of paragraphs, a formal indication of the discursive function of these verbs as organisers of text information.

It can be concluded, therefore, that this pattern reinforces the cohesive value of unaccusative verbs in the corpus analysed. Instead of presenting the Rheme (as shown by Delbecque and Lamiroy, 1999), they recover a previous Theme. This discursive function justifies the use of the singular, and the fact that the Locative argument appears in postverbal position, not as a presentational Focus, but as Rheme information. 


\subsection{Phraseological pattern}

Finally, some of the verbs studied were found to be used in very stable predicative patterns, illustrated in Examples 11 to 14 for aparecer and resultar:

(11) $[\ldots]$ en realidad la solicitud de asilo en el presente caso aparece más fundada en sospechas o conjeturas del peticionario de refugio.

(López Garrido, Diego 1991. El derecho de asilo. Trotta, Madrid, pp. 88-89)

$[(\ldots)$ in fact the request for asylum in this case turns out to be more founded on the asylum seeker's suspicions or conjectures.]

(12) FUNDAMENTOS DE DERECHO

primero. Que aun considerando ser cierto el hecho de que el procesado introdujo en el Depósito Municipal de E. 1,166 gramos de hachís, sin embargo no ha resultado probado que lo hiciera con la finalidad de hacérselo llegar a su presunto amigo E.P.B. (López Garrido, Diego 1991. El derecho de asilo. Trotta, Madrid, pp. 20-21)

\section{[PRINCIPLES OF LAW}

first. That even if it is considered to be true that the accused took into the Municipal Car Pound of E. 1.166 grams of hashish, it has not been proved that he did so in order to deliver it to his alleged friend E.P.B.]

(13) En todo caso, hay que tener en cuenta que las disposiciones contenidas en esta Ley se entenderán sin perjuicio de lo dispuesto en otras normas estatales o autonómicas que resulten de aplicación por razón de la materia.

(Sánchez Almeida, Carlos 2002. La ley de Internet. Régimen jurídico de los Servicios de la Sociedad de la Información y Comercio. SERVIDOC, Barcelona, p. 48)

[In any case, it must be taken into account that the provisions contained in this Law shall be understood without prejudice to the stipulations of other national or regional regulations which may be applicable with regard to this matter.]

(14) [...] todavía hoy se carece de información detallada y suficientemente fiable sobre los diferentes sistemas nacionales de ciencia y tecnología y por eso resulta difícil extraer consecuencias definitivas sobre el rendimiento social de la ciencia y la tecnología. (Quintanilla, Miguel Ángel; Sánchez Ron, José M. 1997. Ciencia, tecnología y sociedad. Santillana, Madrid, p. 6) $[(\ldots)$ detailed and sufficiently reliable information as to the different national systems of science and technology is still lacking today and this is why it is difficult to draw definitive conclusions as to the social yield of science and technology.] 
In Examples 11 to 14 the verbs aparecer and resultar behave as pseudocopulative verbs, and are, thus, followed by participles in aparece fundada (Example 11) and ha resultado probado (Example 12), by a prepositional complement (resulten de aplicación) in (Example 13) and by a qualifying adjective (resulta dificil) in (Example 14). Other examples of this phraseological pattern are the following: aparece redactado el precepto, aparece regulado, aparece firmada, aparecen defendidas; resulta obligado, resulta tipificada; resulta importante/ sorpredente/complejo, etc.

\section{Quantitative results and discussion}

Table 5 shows the percentages of use of the Spanish verbs studied for the first two ${ }^{10}$ patterns mentioned above, according to the specialised field: $(i)$ the pattern in which the verbs present the Rheme (R) with the Subject in postverbal position and (ii) the pattern in which the verb recovers a previous Theme $(\mathrm{T})$ and the Locative element is the Focus.

Each verb shows discourse regularities. In the three fields, the verb existir stands out in the R pattern. Of the five verbs studied, existir is the one that most frequently has the Subject as a postverbal Rheme, as in En este

\begin{tabular}{|l||r|r||r|r||r|r|}
\hline \multirow{2}{*}{ Verbs } & \multicolumn{2}{|c||}{$\begin{array}{l}\text { Science and } \\
\text { Technology }\end{array}$} & \multicolumn{2}{l||}{$\begin{array}{l}\text { Economics and } \\
\text { Finance }\end{array}$} & \multicolumn{2}{|l|}{ Law } \\
\cline { 2 - 7 } & \multicolumn{1}{|c||}{$\mathrm{R}$} & \multicolumn{1}{|c|}{$\mathrm{T}$} & $\mathrm{R}$ & \multicolumn{1}{c|}{$\mathrm{T}$} & $\mathrm{R}$ & $\mathrm{T}$ \\
\hline \hline $\begin{array}{l}\text { existir } \\
\text { 'exist' }\end{array}$ & 81.53 & 18.46 & 81.81 & 18.18 & 77.77 & 22.22 \\
\hline $\begin{array}{l}\text { ocurrir } \\
\text { 'occur' }\end{array}$ & 36.11 & 63.88 & 16.93 & 83.06 & 35.52 & 64.47 \\
\hline $\begin{array}{l}\text { suceder } \\
\text { 'happen/take } \\
\text { place' }\end{array}$ & 72.72 & 27.27 & 42.10 & 57.89 & 34.37 & 65.62 \\
\hline $\begin{array}{l}\text { aparecer } \\
\text { 'appear' }\end{array}$ & 60.86 & 39.13 & 81.25 & 18.75 & 52.38 & 47.61 \\
\hline $\begin{array}{l}\text { resultar } \\
\text { 'turn out' }\end{array}$ & 52 & 48 & 74.54 & 25.45 & 48.88 & 51.11 \\
\hline
\end{tabular}

Table 5: Percentages of the most commonly used verb patterns $\mathrm{R}$ (presenter of Rheme), T (marker of Theme)

\footnotetext{
${ }^{10}$ As for the phraseological pattern of aparecer and resultar, we are not considering them quantitatively because those percentages do not allow comparison between the three subcorpora we are analysing. The collocation of aparecer and resultar with the participle and their appearance with prepositional complements and qualifiying adjectives are only significant in Law texts, not in the other two fields.
} 
punto existen dos posturas antagónicas (1). We observed a similar tendency for suceder in the field of Science and Technology.

As for the verb ocurrir, it was found to be used more frequently in the $\mathrm{T}$ pattern, forming part of a highly stable grammatical structure, proform + verb, where the proform may be the neutral pronoun $l o$, the demonstrative esto or the proadverb así. The verb ocurrir is also frequent in cleft structures which highlight the Subject by means of a relative paraphrasis:

(15) Y, en este sentido, resulta enteramente fundado afirmar que la 'insumisión' de los jueces es muchísimo más grave para el ordenamiento jurídico que la del resto de los ciudadanos.

Pero lo que ocurre es que, en este caso, si es que se puede hablar de 'insumisión' por parte del juez, se trata de una actitud que no tiene un carácter general, sino que se circunscribe a un supuesto muy concreto. (Atienza, Manuel 1993. Tras la justicia. Una introducción al derecho y al razonamiento jurídico. Ariel, Barcelona, p. 162)

[And, thus, it is totally justified to state that the 'insubordination' of judges is much more serious for the legal order than that of other citizens.

But the thing is that (literally, 'what happens is that'), in this case, if this is a case of 'insubordination' by the judge, it is an attitude that is not generalised but limited to a very specific case.]

The verb suceder is mainly used to present the Rheme in the field of Science and Technology (72.72 percent) compared to its predominantly Thematic uses in Law (65.62 percent). Therefore, in the discourse of Science and Technology the verb is used to present 'things that happen' in structures of the type sucede algo, where algo is the Rheme. Furthermore, in Law, comparison and contrast structures frequently use patterns of the type al igual que sucede ('just as happens'), a diferencia de lo que sucede ('unlike what happens'), lo mismo sucede ('the same (thing) happens'), tal y como sucede ('just as happens') and esto es lo que sucede ('this is what happens...'). See also Example 10, above. These specific fields tendencies are related to subject development in each kind of text: as for the discipline of Science and Technology, texts are produced to explain new knowledge in the field or to inform about the causes and effects of scientific phenomena ('Why do they happen?'). As for the discipline of Law, comparison and contrast structures are related to a specific part of legal texts-the socalled 'facts background'. These relations between syntactic and discursive behaviours of those verbs and each type of text are not found in general discourse.

Some other regularities are observed within fields. The verbs aparecer and resultar show higher frequent Rhematic uses in Economics and Finance (81.25 percent and 74.54 percent, respectively) than in the other two disciplines. See the following constructions, related to economic results: 
(16) Aplicando esta fórmula, resulta:... [By applying this formula, it turns out:...]

(17) Aparecería un excedente del factor... [A surplus of the factor would appear...]

(18) Apareció una crisis... [A crisis arose...]

Finally, the specific use of the verbs aparecer and resultar in the field of Law should be stressed. As Examples (11) and (12) above illustrate (aparece fundada and ha resultado probado), these two Spanish verbs are used in a specialised pattern that is typical in Law texts, but not in the other two fields. According to Hanks (2004), these are semantically motivated uses. In other words, the collocation of aparecer and resultar with the participle in a phaseological pattern, and the appearance of prepositional complements and qualifying adjectives are patterns with a meaning that is contextually generated, both by the type of text (specialised in Law) and by the lexicosyntactic structure. As Hanks (forthcoming) has stated:

Teasing out the totality of the complementation patterns in this way is consistent with the Firthian programme of 'knowing a word by the company it keeps' (Firth, 1957). It has only become possible to attempt this with any confidence recently, with the advent of large corpora. Corpus evidence does not enable us to determine all possible usages. No amount of corpus evidence can prove that some linguistic phenomenon cannot exist. Corpus evidence does, however, enable us to determine what patterns of usage are normal, central, and typical and even (with due caution) to say which patterns are the most frequent.

\section{Conclusions and applications}

Three grammatical patterns were identified for the five Spanish verbs studied. The verbs existir, ocurrir, suceder, aparecer and resultar: (a) show an unmarked pattern with the Verb-Subject order described by Spanish grammars; (b) show emphatic, equative or relative structures (not described in reference works) in which the verbs recover a previous Theme in order to contribute further information (see Santos Río, 2003); and (c) are used in some cases in specific predicative constructions (the pseudocopulative verbs aparecer and resultar in the field of Law).

Regarding the second aim of this paper - that is, to determine the scope of use of these verbs in discourse at the local level of the clause or sentence, or to signal the text structure as cohesive markers (Halliday and Hasan, 1976; and Martín Zorraquino and Portolés, 1999)-it was observed that these verbs perform the important function of distributing the information in terms of given and focal (whether new or not). 
As for the inter-relationship of the different levels of text analysis, that is to say, the level of the Thematic organisation of discourse (in terms of Theme, Rheme and Focus), the Syntactic level and the Lexical level, it is important to note that the concept of pattern makes it possible to interrelate grammar and discourse. Two of the grammatical patterns included in this study are associated with two important pragmatic functions of discourse organisation:

(i) a metadiscursive function: the Spanish unaccusative verbs of existence and appearance take part in grammatical patterns that refer to previous or subsequent passages of text; and,

(ii) focalisation: the Spanish unaccusative verbs of existence and appearance form part of patterns that seek to highlight the information that contributes to the reader's stored knowledge.

To summarise, when used in specialised texts, the Spanish unaccusative verbs of existence and appearance studied show characteristic syntactic and discursive behaviours. These conclusions may contribute to grammatical explanations of why and when certain combinations and constructions are used. They may also provide input for dictionaries of use ('codifiers'), in order to enhance information about words whose meaning is sometimes diffuse. We can offer in this way some definition of 'typical' and 'normal' senses of those verbs, based on evidence of actual usage. These precise explanations will contribute to the development of a more competent use of words and text production.

Finally, these findings may be applicable to the teaching and learning of Spanish for specific purposes. Considering that the verbs analysed are part of the general vocabulary, they are accessible to lay people and may offer pointers towards understanding and composing specialised texts. Grammatical patterns of verbs of existence and appearance can be understood as 'conventional preferences', 'normal' uses to have priority in the study of Spanish in specific communicative contexts.

\section{Acknowledgements}

I would like to give special thanks to Susana Rezzano for her useful observations and careful reading of the English version. Montserrat González also made very interesting comments.

\section{References}

Beaugrande, R.A. de. 1984. Text Production: Towards a Science of Composition. Norwood, New Jersey: Ablex Publishing Corporation.

Biber, D. 2005. 'Paquetes léxicos en textos de estudio universitario: variación entre disciplinas académicas', Revista Signos 57, pp. 19-29. 
Biber, D., M. Davies, J.K. Jones and N. Tracy-Ventura. 2006. 'Spoken and written variation in Spanish: a multi-dimensional analysis', Corpora 1 (1), pp. 1-37.

Bosque, I. (ed.). 2004. Redes. Diccionario Combinatorio del Español Contemporáneo. Madrid: SM.

Bosque, I. and V. Demonte (eds). 1999. Gramática descriptiva de la lengua Española. Madrid: Espasa-Calpe.

Cortes, V. 2008. 'A comparative analysis of lexical bundles in academic history writing in English and Spanish', Corpora 3 (1), pp. 43-57.

Delbecque, N. and B. Lamiroy. 1999. 'La subordinación sustantiva: las subordinadas enunciativas en los complementos verbales' in I. Bosque and V. Demonte (eds) Gramática descriptiva de la lengua Española, pp. 1965-2081. Madrid: Espasa-Calpe.

Fernández Ramírez, S. 1985-1987. Gramática Española, 2nd edition redrafted, 5 volumes. Madrid: Arco Libros (I: Prolegómenos; II: Los sonidos; III. 1: El nombre; III. 2: El pronombre; IV: El verbo y la oración. The first four prepared by José Polo; the last, by Ignacio Bosque). [1st edition, Los Sonidos, el Nombre y el Pronombre, Madrid: Revista de Occidente, 1951.]

Firth, J.R. 1957. Studies in Linguistic Analysis. Oxford: Philological Society.

Francis, G. 1991. 'Nominal group heads and clause structure', Word 42, pp. 144-56.

Granger, S. 1998. 'Prefabricated patterns in advanced EFL writing: collocations and formulae' in A.P. Cowie (ed.) Phraseology Theory, Analysis and Applications, pp. 145-60. Oxford: Oxford University Press.

Halliday, M.A.K. 1967. 'Notes on transitivity and theme in English: II', Journal of Linguistics 3 (2), pp. 199-244.

Halliday, M.A.K. 1994. An Introduction to Functional Grammar. (Second edition.) London: Arnold.

Halliday, M.A.K. and R. Hasan. 1976. Cohesion in English. London: Longman.

Hanks, P. 2004. 'Corpus pattern analysis' in Euralex 2004 Proceedings, pp. 87-97. Lorient: Université de Bretagne Sud.

Hanks, P. Forthcoming. Norms and Exploitations: Corpus, Computing, and Cognition in Lexical Analysis. MIT Press.

Hunston, S. 2001. 'Colligation, lexis, pattern, and text' in M. Scott and G. Thompson (eds) Patterns of Text: in Honour of Michael Hoey, pp. 13-33. Amsterdam and Philadelphia: John Benjamins Publishing Company. 
Hunston, S. 2002. 'Pattern grammar, language teaching, and linguistic variation' in R. Reppen, S.M. Fitzmaurice and D. Biber (eds) Using Corpora to Explore Linguistic Variation, pp. 167-83. Amsterdam/Philadelphia: John Benjamins Publishing Company.

Hunston, S. and G. Francis. 1999. Pattern Grammar. A Corpus-driven Approach to the Lexical Grammar of English. Amsterdam and Philadelphia: John Benjamins Publishing Company.

Hyland, K. 2004. Disciplinary Discourses: Social Interactions in Academic Writing. Ann Arbor, Michigan: University of Michigan Press.

Kovacci, O. 1992. 'Fórmulas sintácticas de relieve' and 'El ordenamiento del texto (II). Jerarquización del contenido' in El Comentario Gramatical. Teoría y Práctica II, pp. 212-22, pp. 245-51. Madrid: Arco/Libros.

Levin, B. 1995. English Verb Classes and Alternations: A Preliminary Investigation. Chicago: University of Chicago Press.

López Ferrero, C. 2007. 'Patrones de tema y foco en los discursos de especialidad: esquemas sintácticos y vocabulario en español' in $\mathrm{M}$. Kuteeva and H. Fanha (eds) Teaching and Learning LSP: Blurring Boundaries. Proceedings of the 6th International AELFE Conference, pp. 227-31. Lisbon, Spain.

López Ferrero, C. and S. Torner Castells. 2008. 'Verbos que traban discurso: implicaciones lexicográficas para el DAELE' in E. Bernal and J. DeCesaris (eds) Actas del XIII Congreso Internacional EURALEX: 25 años estudiando diccionarios, pp. 1519-28. Barcelona: IULA-UPF.

Martín Zorraquino, M.A. and J. Portolés. 1999. 'Los marcadores del discurso' in I. Bosque and V. Demonte (eds) Gramática descriptiva de la lengua Española, pp. 4051-213. Madrid: Espasa-Calpe.

Mendikoetxea, A. 1999. 'Construcciones inacusativas y pasivas' in I. Bosque and V. Demonte (eds) Gramática descriptiva de la lengua Española, pp. 1575-629. Madrid: Espasa-Calpe.

Nattinger, J.R. and J.S. DeCarrico. 1992. Lexical Phrases and Language Teaching. Oxford: Oxford University Press.

Oakey, D. 2002. 'Formulaic language in English academic writing' in R. Reppen, S.M. Fitzmaurice and D. Biber (eds) Using Corpora to Explore Linguistic Variation, pp. 111-29. Amsterdam and Philadelphia: John Benjamins Publishing Company.

Partington, A. 1996. Patterns and Meanings: Using Corpora for English Language Research and Teaching. Amsterdam and Philadelphia: John Benjamins Publishing Company.

Piera, C. and S. Varela. 1999. 'Relaciones entre morfología y sintaxis' in I. Bosque and V. Demonte (eds) Gramática descriptiva de la lengua Española, pp. 4367-422. Madrid: Espasa-Calpe. 
Santos Río, L. 2003. Diccionario de Partículas. Salamanca: Luso-Española de Ediciones.

Simpson, R.C. 2004. 'Stylistic features of academic speech: the role of formulaic expressions' in U. Connor and T.A. Upton (eds) Discourse in the Professions: Perspectives from Corpus Linguistics, pp. 37-64, Amsterdam and Philadelphia: John Benjamins Publishing Company.

Sinclair, J. 1991. Corpus, Concordance, Collocation. Oxford: Oxford University Press.

Swales, J. 2001. 'Metatalk in American academic talk: the cases of point and thing', Journal of English Linguistics 29 (1), pp. 34-54.

Trosborg, A. and P.E. Flyvholm Jørgensen (eds). 2005. Business Discourse: Texts and Contexts. Berna: Peter Lang.

Winter, E. 1978. 'A look at the role of certain words in information structure' in K.P. Jones and V. Horsnell (eds) Informatics 3: Proceedings of a Conference Held by the Aslib Co-ordinate Indexing Group, pp. 85-97. 